\title{
INTERNATIONAL CONCEPTIONS OF THE FAMILY
}

\author{
FAREDA BANDA AND John EEKelaAR*
}

\begin{abstract}
This article examines the evolving way the 'family' and 'family life' have been understood in international and regional human rights instruments, and in the case law of the relevant institutions. It shows how the various structural components which are considered to constitute those concepts operate both between relevant adults and between adults and children. But it also shows that important normative elements, in particular, anti-discrimination norms, operate both to undermine the perception of some structures as constituting 'family', and to modify those structures themselves. This raises the question how far human rights norms should be seen as protecting family units in themselves or the individual members that constitute them.
\end{abstract}

Keywords: family, family life, gender discrimination, human rights, marriage, parental relationships, same-sex relationships, violence against women.

\section{INTRODUCTION}

This article considers the understanding of the 'family' (including 'family life') that has developed in the context of major human rights instruments in recent years, and the nature of State obligations to families. It considers whether there might be a movement towards a common understanding of what constitutes a family, in particular how such movement responds to increasing diversity both within societies and in ways of family living, and how it addresses human rights violations happening within family relationships and supports the well-being of family members.

One of the difficulties in the understanding of 'family' is that this involves both matters of structure and value (or norm). Structures can consist of actual or fictitious blood relationships, relationships initiated by formal acts, or ongoing personal relationships. Also, structures may be governed by very different norm systems. For example, compare the cases where there are no rights or obligations between an unmarried father and his child and where there are extensive rights and obligations between them. Although a blood relationship exists in each case, one might plausibly say that in the first case the father is not a member of the 'family' constituted by the mother-child unit

* Professor in Law, School of African and Oriental Studies, fb9@soas.ac.uk; Professor in Law, Pembroke College, University of Oxford, john.eekelaar@law.ox.ac.uk. This research was originally undertaken for UN Women. 
in the same way as he is in the second. Perhaps he is not even a family member at all. One might also view highly patriarchal systems, where a woman and her family have relatively few rights, for example, to succeed to family property, or to pass down status (like nationality) to children, and more equal normative systems as very different types of family form. Similarly, while the formal act of marriage might be the same, the underlying normative structure, and therefore the concept of family, is very different if it is accepted when performed under compulsion, or by someone who is still a child, than where it is held that a family cannot be initiated in those circumstances.

For this reason the article focuses separately on structural and normative elements. Part II considers the social-structural features (such as the presence of formal acts, or blood relationships, or personal relationships) that constitute the elements of the understanding of the 'family' by certain human rights bodies, first with regard only to adults, then with regard to adults and children. In doing this we indicate how these expressions have changed over time, and compare their use between the various bodies. Part III focuses on the way the promotion by human rights bodies of central human rights norms, first with respect to discrimination and next with respect to violence, has affected their conception of what should constitute families and family life, again tracing its development over time. Our overall purpose is to show not only how these bodies have responded to changes in the concept of the family, but also how they have themselves sought to change those concepts. Part IV concludes the article by trying to identify common underlying drivers of change to assist a coherent understanding of the current position.

The main sources used are the European Convention on Human Rights and Fundamental Freedoms 1953 (ECHR), the American Convention on Human Rights 1969 (ACHR), the International Covenant on Civil and Political Rights 1966 (ICCPR), the International Covenant on Economic, Social and Cultural Rights 1966 (ICESCR), the Convention on the Elimination of all Forms of Discrimination against Women 1979 (CEDAW), and the UN Convention on the Rights of the Child 1989 (CEDAW). ${ }^{1}$ Reference will also be made to the African Charter on Human and Peoples' Rights, 1981 (ACHPR); the African Charter on the Rights and Welfare of the Child 1990 (ACRWC); the Protocol to the African Charter on Human and Peoples' Rights on the Rights of Women, 2003 (African Women's Protocol); and the Arab Charter on Human Rights. ${ }^{2}$

1 European Convention on Human Rights (1950) TS 71 (1953); American Convention on Human Rights (1969) OAS TS 36, 1144 UNTS 123; International Covenant on Civil and Political Rights (1966) 999 UNTS 171; International Covenant on Economic, Social and Cultural Rights (1966) 993 UNTS 3; Children's Rights Convention (1989) 1577 UNTS 3; Convention on the Elimination of all forms of Discrimination against Women (1979) 1249 UNTS 13.

2 African Charter on Human and Peoples' Rights (1981) 1520 UNTS 217; African Charter on the Rights and Welfare of the Child (1990) CAB/LEG/24.9/49; Protocol to the African Charter on Human and Peoples' Rights on the Rights of Women (2003) OAU AHG/Res. 240; Arab Charter on Human Rights (2004) reprinted in 12 IHRR 89. We have not included the Convention on the 


\section{A. Purposive Concept}

A general caveat must be entered at the outset to guard against an excessively formalistic approach to this subject. Whether a social unit is perceived (or described) as a family is influenced by the consequences that follow. For example, the purpose for treating people as family is often to allow for community support of the relationship, the establishment of legal duties between them and to provide a fair means of resolving disputes should the relationship fail. If the couple are related by blood (such as siblings) they are of course already family, but whether they would be seen as family for these other purposes could be controversial. In Burden $v U K^{3}$ the European Court of Human Rights held that a cohabitation between sisters was 'qualitatively different in nature' from marriage or civil partnership so that they were not entitled to be treated in the same way for inheritance tax purposes. So while they all constitute families, the purposes for recognizing them as such are different. Also, whether this extends to relationships involving more than one person might raise alarm in some societies. It is for this reason that Coomeraswamy's suggestion that people should have the freedom to define who is a member of their family, though attractive, may meet resistance. ${ }^{4}$

\section{B. The Universal Declaration of Human Rights}

Before proceeding to the analysis, we should observe that the foundation of modern human rights formulations of the family can be traced to the Universal Declaration of Human Rights 1948 (UDHR), Article 16 of which proclaimed: 'The family is the natural and fundamental group unit of society and is entitled to protection by society and the State. ${ }^{5}$ The idea of including the family within the UDHR was not controversial, not least because it was conceived of as the foundation of both society and the State. From the outset, there was universal agreement that consensual heterosexual marriage between adults was a primary indicator of the existence, or start, of family life. ${ }^{6}$ However, as the following analysis shows, a little more than half a century after the UDHR, extremely wide understandings of 'family' can be found. ${ }^{7}$

Rights of Persons with Disabilities (2006), Article 23 of which contains provisions relating to family similar to those found in the earlier instruments. The Committee on the Rights of Persons with Disabilities (CRPD) has not developed an analysis of the 'family' equivalent to that found for the other instruments, and there is no reason to believe that when it does so, this will differ from it.

3 Appl No 13378/05, Judgment of 29 April 2008, para 62.

4 R Coomaraswamy, 'To Bellow like a Cow: Women, Ethnicity and the Discourse of Rights' in R Cook (ed), Human Rights of Women: National and International Perspectives (Penn Press 1994) 39 at 56.

5 Universal Declaration of Human Rights General Assembly resolution 217A, art 16(3).

6 See J Morsink, The Universal Declaration of Human Rights: Origins, Drafting and Intent (Penn Press 2000) Ch 7 for a general discussion.

7 See for example the UN Working Group on Laws and Practices that Discriminate against Women, A/HRC/29/40 (June 2015) para 23: 'The family exists in various forms. The expression 


\section{STRUCTURAL ELEMENTS}

This section focuses on the way the family is perceived by State law. Despite the proclamation in Article 16 of the 1948 UDHR that family is a 'natural' group, ${ }^{8}$ in 2013 the CEDAW Committee observed that the family is 'a social, legal, religious and economic construct'. ${ }^{9}$ This section considers the way in which international law has, over time, sought to shape such constructions by States.

\section{A. Relationships between Adults}

\section{Formal acts and other types of institutional recognition}

The formal institutional act of marriage is commonly seen as a conclusive identifier of 'family'. In 1985 the ECtHR proclaimed in Abdulaziz and others $v$ The United Kingdom that: 'Whatever else the word "family" may mean, it must at any rate include the relationship that arises from a lawful and genuine marriage ... even if a family life of the kind referred to by the government has not yet been fully established.' ${ }^{10}$ Empirical research conducted by Mahy and others in Indonesia showed that women who are divorced or widowed are in many ways still defined by reference to their marital status, suffering negative stereotyping. ${ }^{11}$ In its General Comment 19 in 1990 on the Family, the Human Rights (HR) Committee stated with respect to the ICCPR:

The Committee notes that the concept of the family may differ in some respects from State to State, and even from region to region within a State, and that it is

\footnotetext{
"diverse families" encompasses, for example, single-parent families; families headed by women; intergenerational families including, among others, grandparents; families headed by children, such as orphans or street children; families comprising lesbian, gay, bisexual, transgender and intersex (LGBTI) persons; extended families; self-created and self-defined families; families without children; families of divorced persons; polygamous families; and non-traditional families resulting from interreligious, intercommunity or inter-caste marriages. Self-created and selfdefined families include, in particular, families formed in marginalized communities. In all these different forms of family, women tend to be subject to legal sanctions and to experience difficult social and economic situations. Indigenous and minority women and women living in strict patriarchal, religious, traditional or caste systems are more likely to be found in these forms of family and are especially vulnerable to early and/or forced marriage, while men may have multiple households or second families with their de facto spouses or partners.'

8 See also ACHR, art 17.1; ICCPR, art 23.1; ICESCR, art 10.1; ACHPR, art 18(1); Arab Charter, art 33(1).

9 CEDAW General Recommendation No 29 on Economic consequences of Marriage, Family relations and their dissolution under article 16 of the Convention, CEDAW/C/GC/29 (26 February 2013) para 1. CEDAW General Recommendation No 29 paras 7, 8. See also CEDAW General Recommendation No 28 on the Core Obligations of States Parties under art 2 of the Convention, CEDAW/C/GC/28 (16 December 2010).

${ }^{10}$ Adbdulaziz, Cabales and Balkandali v The United Kingdom Appl No 9474/81, Judgment of 28 May 1985, para 62.

11 P Mahy, MS Winarnita and N Herriman, 'Presumptions of Promiscuity: Reflections on Being a Widow or Divorcee from Three Indonesian Communities' (2016) 44(128) Indonesia and the Malay World 47. J Chandler, Women without Husbands: An Exploration of the Margins of Marriage (Macmillan 1991).
} 
therefore not possible to give the concept a standard definition. However, the Committee emphasizes that, when a group of persons is regarded as a family under the legislation and practice of a State, it must be given the protection referred to in article 23. Consequently, States parties should report on how the concept and scope of the family is construed or defined in their own society and legal system. ${ }^{12}$

Although this statement suggests that the HR Committee will accept as families those social units that States recognize as so constituted, whether by formal acts or by some other mode, under their legislation, this is not completely the case. In 2000, the HR Committee in its General Comment 28 on Article 3 of the ICCPR, which requires equality between men and women, was clear that not all family relationships, even if considered marriages, were compatible with the ICCPR. ${ }^{13}$ It singled out polygyny, levirate marriage ${ }^{14}$ and marriages which followed rape as egregious violations of women's rights which ought to be outlawed. ${ }^{15}$ Families so constituted would not therefore require 'protection'. It reiterated the equality demands made in General Comment $19^{16}$ and reinforced the importance of consent to marriage. ${ }^{17}$ Similarly, the CESCR, although broad in its articulation of family, like the CEDAW Committee, was clear in its dialogue with States parties and concluding observations in 1998 that practices such as polygyny constitute discrimination and are harmful practices that ought to be eliminated. ${ }^{18}$

The introduction of registered (or 'civil') partnerships for same-sex couples created a new dimension into the nature of the 'family'. In 2010, in Schalk and Kopf $v$ Austria ${ }^{19}$ the European Court of Human Rights (ECtHR) recognized that such couples enjoyed 'family life' protected by Article 8, citing a 'rapid evolution of social attitudes towards same-sex couples in many member states', although the exact status and rights conferred by such a framework fell within the State's 'margin of appreciation'. In 2015 the Court went as far as, in effect, to hold that respect for family life demanded at least the

12 UN Human Rights Committee (HRC), CCPR General Comment No. 19: Article 23 (The Family) Protection of the Family, the Right to Marriage and Equality of the Spouses (27 July 1990) UN Doc HRI/GEN/1/Rev.6 at 149 (2003) para 2 (emphasis added). See also UN Human Rights Committee (HRC), CCPR General Comment No. 16: Article 17 (Right to Privacy), The Right to Respect of Privacy, Family, Home and Correspondence, and Protection of Honour and Reputation (8 April 1988) Doc HRI/GEN/1/Rev.6 at 142 (2003) para 5. Finally, see CEDAW General Recommendation No 21 on Equality in Marriage and Family Relations (1994), UN Doc HRI/GEN/1/Rev.9 (vol. II) para 13.

${ }^{13}$ UN Human Rights Committee (HRC), CCPR General Comment No. 28: Article 3 (The Equality of Rights Between Men and Women) (29 March 2000) CCPR/C/21/Rev.1/Add.10.

14 Where a widow is obliged/may be required to marry her deceased husband's brother: ibid para 19. 15 ibid para 24. 16 ibid para $25 . \quad 17$ ibid para 23.

18 UN Committee on Economic, Social and Cultural Rights: Concluding observations: Nigeria (16 June 1998) E/C.12/1/Add.23, available at <http://www.refworld.org/docid/3ae6ae690.html> para 22. (It also cites the beating 'chastisement' by husbands of their wives as a violation: at para 2.)

19 Appl No 30141/04, Judgment of 24 June 2010, para 93. 
availability of some form of formalized relationship for same-sex couples, ${ }^{20}$ while at the same time tolerating a wide variation in the substantive provisions governing such institutions. ${ }^{21}$

In 2013 the CEDAW Committee had noted 'the adoption by some State parties of laws on registered partnerships and/or de facto unions, as well as the increase in the number of couples living in such relationships', ${ }^{22}$ and for the first time acknowledged same-sex relationships:

Certain forms of relationships (namely, same-sex relationships) are not legally, socially or culturally accepted in a considerable number of States parties. However, where they are recognized, whether as a de facto union, registered partnership or marriage, the State party should ensure protection of the economic rights of the women in those relationships. ${ }^{23}$

The CEDAW Committee is here responding to developments in the formal laws of various States, much as the ECtHR has done, while, like that court, at the same time insisting on observance of fundamental normative standards of equality between men and women, though in the case of same-sex relationships, presumably the equality norm applies between the couple, whatever their gender.

In 2015 the European Court of Human Rights was still not ready to hold that same-sex couples had a right to marry. ${ }^{24}$ In 1999 the Human Rights Committee took the same approach towards marriage under the ICCPR in holding that a New Zealand law which at that time defined marriage as being between a man and a woman did not breach the Convention. ${ }^{25}$ This creates a difficulty if one partner in an opposite-sex marriage wishes to change gender. If samesex marriage is not available, the couple may need to divorce and form a civil partnership (if available). In 2014 the ECtHR held, even though there was a right to change gender, this consequence did not breach their Article 8 rights, though the dissenting judges pointed to the distress that could be caused by the requirement to divorce. ${ }^{26}$ The Inter-American Commission and Court have not faced the issue directly, although an application to the Commission in 2012 seeking to require Chile to legalize same-sex marriage was subject to much

20 Oliari and others $v$ Italy, Appl Nos 18766/11 and 36060/11, Judgment of 21 July 2015.

21 For descriptions of the range of 'types' of such institutions in Europe, see I Curry-Sumner, 'Same-Sex Relationships in a European Perspective' in JM Scherpe (ed), European Family Law, vol. III (Edward Elgar 2016) 121-6 and JM Scherpe, The Present and Future of European Family Law (Edward Elgar 2016) 42-51.

22 CEDAW General Recommendation No 29 Economic consequences of marriage, family relations and their dissolution, CEDAW/C/GC/29 (2013) para 6.

${ }^{23}$ CEDAW General Recommendation No 29 para 24. This echoes CEDAW General Recommendation No 28 on State obligations, para 18 and 31 where it calls on States to recognize intersectional discrimination including sexual orientation.

24 Oliari and others $v$ Italy (n 20).

25 Juliet Joslin et al. $v$ New Zealand, Comm No 902/1999, UN Doc A/57/40 at 214 (2002).

26 Hämäläinen v Finland, Appl No 37359/09, Judgment of 16 July 2014. 
negotiation and led to withdrawal of opposition to it by the Chilean government in $2015 .{ }^{27}$ Eventually a civil partnership regime was introduced. ${ }^{28}$

Nevertheless, a growing number of jurisdictions have introduced same-sex marriage, with the decision of the US Supreme Court in Obergefell $v$ Hodges $^{29}$ holding that this was a constitutional right. But it is clear that this decision is one for national jurisdictions. While South Africa enacted the Civil Union Act recognizing same sex marriage in 2006, ${ }^{30}$ in 2014 Nigeria did the reverse, enacting a Same Sex Marriage (Prohibition) Act. ${ }^{31}$ The Arab Charter on Human Rights is clear that marriage is a heterosexual only contract. $^{32}$ The same contrasts are to be found in Europe, where the constitutions of ten countries ban same-sex marriage. ${ }^{33}$ The absence of marriage or civil partnership withdraws from same-sex couples a formal method which will usually be held sufficient to constitute 'family' in the case of opposite-sex couples. Nevertheless an interpretation the IAC has given to the meaning ascribed to 'life' protected under Article 4 of the ACHR has broadened its meaning to encompass a right to a 'life plan'. While originally applied in the contexts of torture and street children, ${ }^{34}$ its potential was expressed by Justice Marco Aurelio in the Federal Supreme Court of Brazil on 5 May $2011^{35}$ in the context of discrimination on the ground of sexual orientation:

The State exists to support individuals in the realization of their personal life plans, which translate into the free and full development of the personality. ... The dignity of life requires the possibility of concretizing goals and projects. From that premise, the issue of existential harm arises when the State restricts the citizens in this aspect. It is worthy to be said: that the State is obligated to guarantee that individuals search for their own happiness, as long as they do not violate the rights of others, which does not occur in the present case. It is true that the life project of those attracted by the same sex would be harmed

27 See <http://www.washingtonblade.com/2015/02/18/chilean-government-end-oppositionsex-marriage/ $>$.

${ }_{28}$ See <http://www.theguardian.com/world/2015/oct/22/chiles-same-sex-couples-celebratecivil-unions $>$. 29135 S.Ct. 2584, 2594 (2015).

30 Civil Union Act 17 of 2006. The preamble recalls section 9(3) of the Constitution which outlaws discrimination on grounds of sexual orientation.

31 Kaleidescope Trust, Nigeria: Same Sex Marriage (Prohibition) Act, Kaleidescope Trust Briefing (January 2014) at:<http://kaleidoscopetrust.com/usr/library/documents/main/2014-02nigeria.pdf $>$.

33 See Curry-Sumner (n 21) 121.

34 See L Burgorgue-Larsen and A Ubeda de Torres, The Inter-American Court of Human Rights: Case Law and Commentary (Oxford University Press 2011) paras 10.16-18. See IAHCR, Advisory Opinion No 17/2002, para 80: 'Regarding conditions for care of children, the right to life that is enshrined in Article 4 of the American Convention does not only involve the prohibitions set forth in that provision, but also the obligation to provide the measures required for life to develop under decent conditions.'

35 See Inter-American Commission on Human Rights, Legal Standards Related to Gender Equality and Women's Rights in the Inter-American Human Rights System: Development and Application, Updates 2011-2014. 
with the absolute impossibility of creating a family. To expect from them a change of sexual orientation so that they are capable of reaching that legal situation shows a lack of appreciation of dignity. It is also faced with the constitutional objection to prejudice by reason of sexual orientation.

Similar references to the importance to individuals of respecting their 'life plan' are found in the 2012 decision of the IAC in Atala Riffo and Daughters $v$ Chile. ${ }^{36}$ It seems but a short step to say that if it is part of the 'life plan' of a same-sex couple to live as married, this should then include the right to marry.

\section{Blood relationships}

It seems that a number of elements are capable of being seen as constituting a family relationship. These may sometimes coincide with other elements, but may also occur singly. A blood relationship is one such element. Such relationships alone can be especially significant in identifying family members across time, either to provide revelations of genetic inheritance and identity, ${ }^{37}$ or to regulate succession to property or social status according to the rules of individual societies. ${ }^{38}$ Such rules have tended to privilege males over females, ${ }^{39}$ and successors over widows, who have often effectively lost their status as a family member for these purposes. Blood relationships can establish support duties, most commonly, of course, between parent and child (and sometimes grandchildren), though sometimes more widely (say, between siblings). Nevertheless, since this is a 'purposive' concept (as explained above), in some jurisdictions a blood relationship between adults will not always be held to constitute family life. In FNv The United Kingdom, the ECtHR confirmed that 'there will be no family life, within the meaning of Article 8, between

36 Inter-American Court of Human Rights: Case of Atala Riffo and Daughters $v$ Chile, Judgment of 24 February 2012 (Merits, Reparations and Costs) paras 136, 156.

37 Perhaps the most striking illustration of this came in Hopu and Bessert $v$ France, Comm No 549/1993 (30 October 1995). In an attempt to block a hotel building project in French Polynesia (Tahiti), a challenge was brought by a group of people who alleged that the land on which the hotel was to be built contained the bones of their ancestors which were important to their history, culture and life. The HR Committee found that there had indeed been violations of the authors' private and family rights under Articles 17(1) and 23(1), saying: 'The Committee observes that the objectives of the Covenant require that the term "family" be given a broad interpretation so as to include all those comprising the family as understood in the society in question. It follows that cultural traditions should be taken into account when defining the term "family" in a specific situation. It transpires from the authors'claims that they consider the relationship to their ancestors to be an essential element of their identity and to play an important role in their family life. ... The Committee ... concludes that the construction of a hotel complex on the authors' ancestral burial grounds did interfere with their right to family and privacy.'

38 In Mitzinger $v$ Germany (Appl No 29762/10, Judgment of 9 February 2017) it was held that the principle of excluding children born out of wedlock from inheriting if they were born before a certain cut-off point was discriminatory. It was further noted that the trend in European case law and national legislation was towards 'eliminating all discrimination regarding the inheritance rights of children born outside of marriage'.

39 For examples, see A Mishra, 'Devolution of Property of the Hindu Female: Autonomy, Relationality and the Law' (2015) 29 International Journal of Law, Policy \& the Family 149. 
parents and adult children or between adult siblings unless they can demonstrate additional elements of dependence and that similar considerations apply to other familial relations such as that between aunt and niece'. ${ }^{40}$

Although expressed in the context of adult-child relationships, Article 5 of the UNCRC expressly refers to recognizing the responsibilities of members of the extended family towards children, which implicitly accepts a family relationship between an adult and child traceable through blood relationships between adults. In paragraph 59 of its 2013 General Comment 14, the Committee on the Rights of the Child confirmed a wide concept of the family:

The term family must be interpreted in a broad sense to include biological, adoptive or foster parents, or, where applicable, members of the extended family or community as provided for by local custom.

In fact, while this sees blood ties as constituting a family relationship not only between the adults and the child but also between the adults who are so related to the child, it is not limited to blood ties and can include within it the extended family relationships constituted by other forms of institutional recognition.

\section{Personal relationships}

In 1986 the ECtHR accepted that a 'family' could exist between unrelated adults without a formal act. In Johnston $v$ Ireland ${ }^{41}$ it held that an Irish couple who had lived together for 15 years but could not marry because the man was already married, divorce being unavailable, enjoyed 'family life' both with each other and with their daughter, although it concluded that its limited recognition by Irish law did not fail to respect the family life between the couple. In that case the couple would have outwardly appeared like any married couple. The Court has since expanded this position, stating, in 1996, that even cohabitation was not essential, as 'exceptionally, other factors may also serve to demonstrate that a relationship has sufficient constancy to create "de facto" family ties' ${ }^{42}$ The birth of a child will commonly suffice. In 1997 the Court expressed it thus: "When considering whether a relationship can be said to amount to "family life" a number of factors may be relevant, including whether the couple live together, the length of their relationships and whether they have demonstrated their commitment to each other by having children together or by other means' ${ }^{43}$

The statement of the HR Committee quoted above 44 that 'when a group of persons is regarded as a family under the legislation and practice of a State, it

40 Appl No 3202/09, Judgment of 17 September 2013. See also AS v Switzerland Appl No 39350/13, Judgment of 30 September 2015.

${ }_{41}$ Appl No 9697/82, Judgment of 18 December 1986.

42 Kroon $v$ The Netherlands Appl No 18535/91, Judgment of 27 October 1994 (emphasis added).

43 X, Y and Zv United Kingdom Appl No 21830/93, Judgment of 22 April 1997.

${ }^{44}$ UN Human Rights Committee (HRC), CCPR General Comment No. 19: Article 23 (The Family) Protection of the Family, the Right to Marriage and Equality of the Spouses (27 July 1990) para 2. 
must be given the protection referred to in article 23 (of the ICCPR)' simply asserts that States are at least obliged to protect those social units which they regard as families. It does not preclude the HR Committee from adopting its own, and possibly wider, definition of a family, as it did in Hopu and Bessert $v$ France, ${ }^{45}$ referred to above. In Balaguer Santacana $v$ Spain, in 1990, the HR Committee noted that 'the term "family" must be understood broadly' but went on to say that 'Some minimal requirements for the existence of a family are however necessary, such as life together, economic ties, a regular and intense relationship, etc. ${ }^{46}$ This suggests that a personal relationship may be a necessary element, even where a blood relationship, or valid formal act, is present. Furthermore, in 2004, in Ngambi and Nebol v France, ${ }^{47}$ the author was denied a visa for his wife to join him in France where he had been granted asylum on the basis that the marriage he had entered into in 1983 was a sham. The HR Committee recalled that "the term "family" for purposes of the ICCPR, must be understood broadly as to include all those comprising a family as understood in the society concerned' and that ' $[\mathrm{t}] \mathrm{he}$ protection of such family is not necessarily obviated, in any particular case, by the absence of formal marriage bonds, especially where there is a local practice of customary or common law marriage' and that '[n]or is the right to protection of family life necessarily displaced by geographical separation, infidelity, or the absence of conjugal relations'. However, it concluded that 'there must first be a family bond to protect' ${ }^{48}$ (The marriage certificate was said not be genuine and the author had a child with another woman.) The claim failed. This suggests that an appropriate personal relationship may be both a necessary and sufficient condition to establish family life.

Willingness to treat personal relationships as a sufficient element to constitute a family is put to severe test in the case of same-sex relationships. The issue first arose in the context of anti-discrimination provisions. Where the law grants certain rights to unmarried opposite-sex couples, the question arises whether they should be provided for same-sex couples too. In 2003, in Karner v Austria $^{49}$ the ECtHR held that not to do so violated anti-discrimination provisions of the ECHR and in 2005 the Human Rights Committee came to the same conclusion with regard to pension rights in Colombia in respect of Article 26 of the ICCPR ('All persons are equal before the law and are entitled without any discrimination to the equal protection of the law.'). ${ }^{50}$ And in 2011 the very same issue, again with respect to Colombia, was held

${ }^{45}$ Comm No 549/1993, 30 October 1995.

${ }^{46}$ Comm No 417/1990, UN Doc CCPR/C/51/D/417/1990 (1994) para 10:2.

47 CCPR/C/81/D/1179/2003,UN Human Rights Committee (HRC) (16 July 2004).

48 ibid para 6:4.

49 Appl No 40016/98, Judgment of 24 July 2003. See also EB v France Appl No 43546/02, Judgment of 22 January 2008. But breach will not have occurred if a heterosexual person or persons would have been in the same position: Gas and Dubois v France, Appl No 25951/07, Judgment of 15 March 2012.

${ }^{50}$ Xv Colombia Comm No 1361/05. 
by the Inter-American Commission on Human Rights to constitute an admissible claim with respect to the anti-discrimination provision of the ACHR (Article 24: 'All persons are equal before the law. Consequently, they are entitled, without discrimination, to equal protection of the law.'). ${ }^{51}$

But to recognize same-sex relationships as 'family' is a further step. As stated earlier, it was only in 2010, in Schalk and Kopf $v$ Austria, ${ }^{52}$ that the ECtHR recognized that such couples enjoyed 'family life' protected by Article 8 of the European Convention. In 2012, in Atala Riffo and Daughters $v$ Chile, 53 the Inter-American Court (IAC) not only upheld a claim that a lesbian mother had been discriminated against on the ground of her sexual orientation contrary to Article 24 of the AHRC in a custody issue but also announced that the 'family' referred to in Articles 11 and 17 was not only the 'traditional' one. The IAC stated that 'the American Convention does not define a limited concept of family, nor does it only protect a "traditional" model of the family. In this regard, the Court reiterates that the concept of family life is not limited only to marriage and must encompass other de facto family ties in which the parties live together outside of marriage.' 54

\section{B. Adults and Children}

\section{Formally constituted relationships}

In 1988, in Berrehab v The Netherlands, the ECtHR held that 'a child born of such a union (ie marriage) is ipso facto part of that relationship hence, from the moment of the child's birth and by the very fact of it, there exists between him and his parents a bond amounting to "family life" even if the parents are not living together'. But it conceded that '[s]ubsequent events may, of course, break that tie'. ${ }^{55}$ It has been maintained that a parental relationship can be established by intent. ${ }^{56}$ In cases of donor assisted conception, or surrogate birth, some systems allow the spouse, civil partner or even someone in a significant relationship with the birth mother to become the child's second parent if they agree this, but the donor or surrogate are excluded. ${ }^{57}$ British Columbia however allows a gamete donor or surrogate mother also to become a 'parent' of the child if all parties agree, resulting in the child having three parents. ${ }^{58}$ But, while intention is an essential element, the

51 Report No 150/11, Petition 123-05-Admissibility: Ángel alberto duque: Colombia (2 November 2011).

52 Schalk and $\operatorname{Kopf}(\mathrm{n} 19)$.

${ }_{53}$ Case of Atala Riffo and Daughters v Chile, Judgment of February 24, 2012 (Merits, Reparations and Costs).

55 Appl No 10734/84, Judgment of 21 June 1988, para 21.

56 RF Storrow, 'Parenthood by Pure Intention: Assisted Reproduction and the Functional Approach to Parentage' (2002) 53 Hastings Law Journal 597.

57 For example the UK Human Fertilisation and Embryology Act 2008 sections 35, 37, 42-47, 54. In the case of surrogacy, parenthood is transferred to the commissioning parents by a 'parental order'. See also Family Law Act 1975, section 60H (Australia).

58 Family Law Act 2011 (BC) sections 29, 30. 
circumstances are strictly defined by law. It does not mean that a family relationship can be established by simply declaring: 'we are now family'.

A formal act of a different kind is described in a California case described by Melanie Jacobs, ${ }^{59}$ Buzzanca $v$ Buzzanca, ${ }^{60}$ where an opposite-sex couple agreed to have an embryo genetically unrelated to either of them implanted in a surrogate, but subsequently divorced and refused to accept the child. As the surrogate had expressly stipulated that she would not be the child's parent, the California trial court decided the child had no lawful parents. The appellate court disagreed, stating that the couple's initial agreement to become parents constituted them as such. Here the intention to exercise parental responsibilities had not been carried into effect, even momentarily. However, there was a formal agreement about who was to be responsible for a child, followed by the implantation of an embryo, birth of the child and attempt by the gestational mother to have the agreement implemented.

But, while formal acts, such as those in Buzzanca, or, more commonly, adoption, may be sufficient to constitute family life, this will not always be the case. In 2013 in $A S v$ Canada the HR Committee refused a claim of a breach of Article 23 of the ICCPR in a case brought by a Canadian woman who was seeking to bring an adult adopted daughter and her child to live with her in Canada. ${ }^{61}$ The applicant mother and now grown child had only lived together for two years in Canada before the adopted daughter had returned to live in Poland from where she had been adopted. They had not lived together in the 17 years preceding the bringing of the action. The HR Committee found that there was not a 'prolonged family life' and thus there could not be a breach of Article 23. One can surmise that had there been a de facto family life, then the adoption would have been sufficient proof of family for the purposes of establishing Article 23 rights, but one wonders whether the approach would have been the same if the case had concerned a biological daughter.

\section{Blood relationships}

In the case of a child born within marriage, two elements are present, birth within a formally recognized structure and a genetic relationship. In 1979 the ECtHR had, in the Marckx judgment, recognized that a relationship between a mother and the child to which she has given birth, whether within or outside marriage, is 'one form of family', though it also remarked on the fact that the mother in that case had cared for her daughter so 'real family life existed and still exists between them'. ${ }^{62}$ It also existed between the child and wider blood

59 MB Jacobs, 'Applying Intent-based Parentage Principles to Non-legal Lesbian Coparents' (2015) 25 Northern Illinois University Law Review 433.

6072 Cal. Rptr. 2d 280 (Cal. Ct. App. 1998).

${ }^{62}$ Marckx v Belgium Appl No 6833/74, Judgment of 13 June 1979.

61 Comm No 68/80. 
relatives, 'for instance, those between grandparents and grandchildren, since such relatives may play a considerable part in family life'. ${ }^{63}$

A blood relationship (or genetic link) is however not necessarily sufficient, or necessary, to establish a familial relationship. Adoption is an obvious example, where blood relationships may be replaced by legal ones in the construction of a family, but even here rights of access to information about birth parents, now quite common, suggests the persistence of a more complex idea of family relationships. The laws on this can be complex, and vary between jurisdictions, Some, like Germany, are very reluctant to disturb the social, or legal, parentage, although it would be difficult to deny a biological father contact rights if this was in the child's interests. ${ }^{64}$ The matter has become especially complex in cases of artificial reproduction and surrogacy. Here the possibilities for creating a familial link are wide: it could be on the basis of gestation, or genetics, or intent. These differences can create major problems in the international context, which international human rights instruments have yet to address. ${ }^{65}$

\section{Personal relationships}

In Johnston v Ireland (1986), ${ }^{66}$ where 'family life' was held to exist between the unmarried couple and their daughter, they would have had the outward appearance of a 'traditional' family. From the 1990s the cases show the court expanding the scope of the 'personal relationship' element. In Keegan v Ireland, ${ }^{67}$ decided in 1994, an unmarried woman gave birth when she was engaged to the father. The conception had been deliberately planned. The relationship broke down, and the mother placed the child for adoption. The father had seen the child when it was one day old, but not since. Nevertheless, the ECtHR held that 'family life' existed between him and his daughter because the genetic element was accompanied by the two-year relationship he had had with the mother and the birth was intended. In two subsequent cases, Boughanemi v France in $1996^{68}$ and Söderback v Sweden in $1998,{ }^{69}$ the ECtHR held that family life existed between a father and his non-marital child even though there was minimal contact between them. But

63 ibid para 45. Article 18 of the African Charter on the Rights and Welfare of the Child 1990 notes that the child should not be deprived of maintenance 'by reference to its parents' marital status'.

${ }_{64}$ Ahrens and Kautzor v Germany Appl Nos 45071/09 and 23338/09, Judgment of 22 March 2012; see D Martiny, 'The Changing Concept of "Family" and Challenges for Family Law in Germany' in JM Sherpe (ed), European Family Law, vol 2 (Edward Elgar 2016) 75-6.

65 See K Trimmings and P Beaumont (eds), International Surrogacy Arrangements: Legal Regulation at the International Level (Hart Publishing 2013).

${ }_{66}$ Appl No 9697/82, Judgment of 18 December 1986.

67 Appl No 16969/90, Judgment of 26 May 1994.

68 Appl No 22070/93, Judgment of 24 April 1996.

69 Appl No 113/1997/897/1109, Judgment of 28 October 1998. 
much might depend on the circumstances of the conception and birth. It is unlikely that a man whose sperm is mistakenly used in IVF treatment resulting in the birth of a child he has not seen will have 'family life' with the child. ${ }^{70}$

In those cases the 'personal relationship' element was combined with a genetic one. But could the social element stand alone in establishing family life between an adult and a child, just as it can between two adults of the opposite sex, as described above? In 1997 the ECtHR held that a female to male transsexual (who was treated in law as a biological female) could have 'family life' with his female partner and her child although there was no genetic relationship between him and the child. ${ }^{71}$ It is notable that, in doing so, the ECtHR observed that the applicant had assumed the physical appearance of a man, and they 'to all appearances lived as a traditional family'. ${ }^{72}$ In 2015, in Paradiso and Campanelli $v$ Italy, ${ }^{73}$ the ECtHR demonstrated that, as regards adult and child, such a relationship could be established very rapidly. An Italian couple had arranged for a surrogate birth in Russia. In bringing the child to Italy, they contravened Italian law, and it turned out that the child had not been conceived through their genetic material. They were therefore neither the child's genetic nor legal parents, and the Italian authorities thereupon removed the child (who was some nine months old) from them. The ECtHR held not only that 'family life' existed between the couple and the child, but that the Italian authorities had failed to act 'proportionately' in separating them in view of the need to give paramount consideration to the child's best interests. ${ }^{74}$ The ECtHR observed that respecting family life did not safeguard a 'desire' to form a family, but that they had acted as parents to the child (to whom they were neither legally nor genetically related) for a period of six months. ${ }^{75}$

So it seems that for the purposes of the ECHR, an 'adult-child' family can be constituted by virtue of a close social relationship even if there is no blood relationship involved. In 2002 the IAC suggested it could reach a similar conclusion when, in giving an Advisory Opinion on Children's Rights, it seemed to use 'family' interchangeably with 'household': 76

In conclusion, the child must remain in his or her household, unless there are determining reasons, based on the child's best interests, to decide to separate him or her from the family. In any case, separation must be exceptional and, preferably, temporary.

70 Leeds Hospital NHS Trust v A [2003] 1 FLR 1091 (England and Wales Court of Appeal).

$71 X, Y$ and $Z v$ United Kingdom Appl No 21830/93, Judgment of 22 April 1997.

72 ibid at para $33 . \quad 73$ Appl No 25358/12, Judgment of 27 January 2015.

74 The case has been referred to the Grand Chamber for further consideration.

75 Paradiso (n 73) at paras 67 and 69.

76 IACHR, Advisory Opinion No 17/2002, para 77 (emphasis added). 
These passages indicate that in the case of adults living with children, either the concept of 'family' will be used to encompass adults and children living in close social relationships, or some other word will be used (like 'household') where it is necessary to give the relationship protection.

As regards the UNCRC, it is notable that its articles are designed to ensure that a child's existing relationships are protected. For example, Article 8 was designed to protect children against being taken from their families as a mode of political persecution ${ }^{77}$ and this speaks of preserving family relationships; Article 10 expressly refers to family reunification; Article 16 refers to interference with a child's family and Article 37 to maintaining contact. Yet in its General Comment No 14, in 2013, ${ }^{78}$ the Committee on the Rights of the Child, in a subsection ${ }^{79}$ headed 'Preservation of the family environment and maintaining relations' referred to Article 16 as establishing the 'right of the child to family life', ${ }^{80}$ which could have a wider scope. UNICEF also claims that a series of Articles of the UNCRC protect such a right. ${ }^{81}$ But this is correct only insofar as such rights include the right that existing family life should not be disturbed, but not if it is to mean that they establish a right to acquire a family life. This is important in the context of adoption, especially international adoption, where the 'right to a family life' has been put forward as a basis for a duty upon States to make provision for intercountry adoption. ${ }^{82}$ Yet Article 21(b), which deals with adoption, creates a much weaker obligation, namely, that States should 'recognize that intercountry adoption may be considered as an alternative means for a child's care, if the child cannot be placed in a foster or adoptive family or cannot in any suitable manner be cared for in the country of the child's origin'. Article 24(b) of the African Charter on the Rights and Welfare of the Child makes it clear that intercountry adoption should be regarded as 'a last resort' to be used if alternative in-country options are not available.

Although the UNCRC does not create any right to be adopted, adoptive relationships are clearly included in the concept of 'family' used by the UNCRC. In paragraph 59 of its 2013 General Comment 14, the Committee on the Rights of the Child sets out a wide concept of the family:

The term family must be interpreted in a broad sense to include biological, adoptive or foster parents, or, where applicable, members of the extended family or community as provided for by local custom.

77 See S Detrick, A Commentary on the UN Convention on the Rights of the Child (Martinus Nijhoff 1999) 292. $\quad{ }_{78}$ CRC/C/14 (2013). $\quad{ }^{79}$ CRC/C/14 (2013) section V.A.1(c).

${ }^{80} \mathrm{CRC} / \mathrm{C} / 14(2013)$ para 59.

81 Arts 5, 8, 9, 10, 16, 18, 27: see UNICEF, Written Submission, The Rights of All Children in the Context of International Migration: <http://search.ohchr.org/results.aspx? $\mathrm{k}=$ family $\% 201$ life $>$.

82 See M Neagu, 'Children by Request: Romania's Children between Rights and International Politics’ (2015) 29 International Journal of Law, Policy \& the Family 215. 
The inclusion of 'foster parents' allows for those systems that do not recognize the institution of adoption, but permit alternatives. But it also includes the kind of fostering common in child welfare contexts which exist alongside adoption. Paragraph 70 of General Comment 14 uses the term 'family environment' to extend the concept even further:

Preservation of the family environment encompasses the preservation of the ties of the child in a wider sense. Those ties apply to the extended family, such as grandparents, uncles/aunts as well as friends, school and the wider environment and are particularly relevant in cases where the parents are separated and live in different places.

The expression 'family environment' seems to refer to the complex of relationships in which the family is situated. It is easy to understand why such a broad concept can arise in a context where the primary goal is to prevent disruption of a child's current relationships, for these relationships are often interconnected and many are important to the child. The Committee on the Rights of the Child has commended a similarly wide conception of the 'family' in the context of a discussion on the protection of children against violence:

The references to 'family' (or to 'parents') must be understood within the local context and may mean not only the 'nuclear' family, but also the extended family or even broader communal definitions including grandparents, siblings, other relatives, guardians or careproviders, neighbours, etc. ${ }^{83}$

Similarly, Article 25 of the African Charter on the Rights and Welfare of the Child 1990 suggests that children separated from their parents, or who are 'parentless', be provided with 'alternative family care, which could include foster placement'. Should the children be separated from their parents in war or times of crisis, then they should be placed with 'relatives'.

\section{The Role of the 'Best Interests' Principle}

Article 3(1) of the UNCRC states that: 'In all actions concerning children, whether undertaken by public or private social welfare institutions, courts of law, administrative authorities or legislative bodies, the best interests of the child shall be a primary consideration.' This could form the basis for requiring States to give certain de facto familial relationships legal recognition where this is in the child's best interests.

In its 2002 Advisory Opinion on the interpretation of Articles 8 and 25 of the ACHR, which pertain to fair trial and judicial protection, insofar as they affected children, the IAC gave a wide ranging appraisal of children's rights issues under the ACHR. ${ }^{84}$ Most notably it imported the 'best interests of the child' principle into the interpretation of that Convention, saying:

\footnotetext{
83 Committee on the Rights of the Child, 28th Session, 24 September to 12 October $2001 \mathrm{CRC} /$ C/111 (28 November 2001) para 701. ${ }^{84}$ IACHR, Advisory Opinion No 17/2002.
} 
... the phrase 'best interests of the child', set forth in Article 3 of the Convention on the Rights of the Child, entails that children's development and full enjoyment of their rights must be considered the guiding principles to establish and apply provisions pertaining to all aspects of children's lives. ${ }^{85}$

In the same way, the ECtHR has 'imported' the best interests principle into its application of the proportionality test when considering competing rights under Article 8 of the ECHR (the right to respect for private and family life). ${ }^{86}$

The effect of the principle on the construction of a family appears in UK legislation, ${ }^{87}$ where the strict provisions governing the transfer of parental status (such as time limits) by a 'parental order' in cases of surrogacy have been waived by courts if this is in the child's best interests. ${ }^{88}$ Even in countries where surrogacy is prohibited, such as Germany and France, the interests of the child in having a legally recognized parent can lead to modification of strict legal provisions. ${ }^{89}$ This position is strengthened by empirical evidence that strongly indicates that children brought up by samesex parents do as well, and sometimes better, than those brought up by opposite-sex parents. ${ }^{90}$

\section{NORMATIVE ELEMENTS}

We now turn to a consideration of the importance, especially under the conventions considered in this article, of normative issues, because, even if the relevant human rights institutions may accept different countries' views about the formal structures that constitute a family, they are certainly not prepared to endorse all the norms governing relationships between family members. In these cases, therefore, States may be under an obligation to remove laws that perpetuate discriminatory practices, or in some circumstances, to intervene within a family to bring about behavioural change. In this way the normative content that is associated with the concept of the family is changed. It is often said that with rights come responsibilities. The African human rights system is clear in noting that an individual has duties to his family, while the child has a duty to obey his or her elders. ${ }^{91}$ However, commentators have noted that these obligations

${ }^{85}$ IACHR, Advisory Opinion No 17/2002, para 2 of the Opinion.

${ }^{86}$ Yousef $v$ The Netherlands Appl No 33711/96, Judgment of 5 November 2002, para 73.

${ }^{87}$ Human Fertilisation and Embryology Act 2008, sections 42(1), 48.

88 re X (A Child) (Surrogacy: Time Limit) [2014] EWHC 3135 (Fam).

89 See J Scherpe, The Present and Future of European Family Law (Edward Elgar 2016) 96-7; Mennesson v France, Appl No 65192/11, Judgment of 26 June 2014.

${ }^{90}$ See S Golombok, Modern Families: Parents and Children in New Family Forms (Cambridge University Press 2015). This is extensively discussed by the Inter-American Court of Human Rights in Case of Atala Riffo and Daughters v Chile, Judgment of February 24, 2012 (Merits, Reparations and Costs).

${ }_{91}$ African Charter on Human and Peoples' Rights (1981) OAU CAB/LEG/24.9/49 arts 27-29; African Charter on the Rights and Welfare of the Child (1990) OAU Doc CAB/LEG/24.9/49, art 31. 
should be understood as subject to principles of non-discrimination and the avoidance of harm to the individual..$^{92}$

\section{A. Discrimination}

In arguing that it is possible to detect 'certain underlying principles' that warrant labelling certain elements of family law 'European Family Law', Jens Scherpe places great emphasis on the role of equality between spouses and the principle of non-discrimination to be found in European instruments and jurisprudence. ${ }^{93}$ To be sure, Scherpe does not claim this to be unique to Europe, and this is important because, as the following discussion shows, the norms of equality and anti-discrimination have been powerful factors in forming an international perception of how laws should shape family living. ${ }^{94}$

The disapproval of discrimination was made clear with regard to the ICCPR in 1981 in a case ${ }^{95}$ where three women challenged Mauritian immigration law which permitted men to bring in alien wives, but which required the alien husbands of Mauritian women to seek permits. They said the law constituted discrimination and an arbitrary and unlawful breach of their right to family life. Accepting that a family had been constituted by the formal act of marriage, the HR Committee said that, while it was 'of the opinion that the legal protection or measures a society or a State can afford to the family may vary from country to country and depend on different social, economic, political and cultural conditions and traditions', ${ }^{96}$ nevertheless the nondiscrimination and equality provisions found in Articles 2(1), 3 and 26 had to guide the interpretation of the substantive provisions, including Article 23 on the family. ${ }^{97}$ 'It follows that also in this line of argument the Covenant must lead to the result that the protection of a family cannot vary with the sex of the one or the other spouse. ${ }^{98}$

92 C Beyani, 'Toward a More Effective Guarantee of Women's Rights in the African Human Rights system' in R Cook (ed), Human Rights of Women: National and International Perspectives 285; T Kaime, The African Charter on the Rights and Welfare of the Child: A Socio-Legal Perspective (Pretoria University Law Press 2009).

93 See Scherpe (n 89) 2-5, 57. See also Markin v Russia, Appl No 30078/06, European Court of Human Rights (Grand Chamber), Judgment of 22 March 2012 challenging gender stereotyping parental leave roles which did not give fathers the same rights as mothers.

${ }^{94}$ The universality of the non-discrimination principle was reinforced by the IACHR in InterAmerican Court of Human Rights, Advisory Opinion, OC-18/03, 17 September 2003, Inter-Am. Ct HR, (Ser. A) No. 18 (2003) paras 82-110. It was also endorsed by the African Commission Comm No 323/2006 Egyptian Personal Rights Project and Interights v Egypt, paras 117-180.

${ }_{95}$ Shirin Aumeeruddy-Cziffra and 19 Other Mauritian Women v Mauritius, CCPR/C/12/D/35/ 1978, UN Human Rights Committee (HRC) (9 April 1981) available at $<$ http://www.refworld.org/ docid/3f520c562.html >. See generally Equality Now, The State We Are in: Ending Sexism in Nationality Laws (Equality Now 2015). $\quad{ }^{96}$ ibid para 9.2(b)2(ii) 1.

97 ibid para 9.2(b)2(ii) 2 .

98 ibid para 9.2(b)2(ii) 3. A similar finding was made in an 'internal migration case' where Canada refused to give the same family-related benefits to indigenous women who married outside the group that it afforded to indigenous men who did the same. The majority found that 
In its 1990 General Comment 19, the HR Committee said:

Recalling the Convention on the Nationality of Married Women (1957) it further enjoins States to ensure that 'no sex-based discrimination should occur in respect of the acquisition or loss of nationality by reason of marriage'. The right of spouses to keep their names or to choose a family name is recognized while the importance of ensuring equal rights and responsibilities in the family is reinforced. This equality extends to all matters arising from their relationships, such as choice of residence, running of the household, education of the children and administration of assets. Such equality continues to be applicable to arrangements regarding legal separation or dissolution of the marriage. ${ }^{99}$

Of all the UN human rights treaty mechanisms, CEDAW is the one which has paid the most attention to family and marriage. The reasons for this are obvious: a Convention focused on eliminating discrimination against women perforce has to examine the areas in which they face the most discrimination. Social and legal history highlights that private sphere, family or personal statusrelated discrimination is the area that has most impacted negatively on women. CEDAW seeks to capture the challenges faced by women in the family, community and work place and to direct State attention to these areas. ${ }^{100}$ Although Article 16 of CEDAW is titled marriage and family, there are many other provisions which interrelate, not least Article 5 on gender stereotyping. Despite the Committee's many entreaties to States Parties to refrain from entering reservations, or to withdraw those already made, Articles 2 (on State obligations), 9 (on nationality) and 16 remain the most heavily reserved substantive provisions in CEDAW. ${ }^{101}$

The CEDAW Committee employs a strong equality norm in its approach to family issues. It is noteworthy that the framing of discrimination in Article 1 of CEDAW includes the phrase 'irrespective of their marital status'. In its interaction with States, the focus of CEDAW when considering Article 16 is on the way in which women experience family-related discrimination. ${ }^{102} \mathrm{Can}$ they get divorced? Do they have equal right to property on death and divorce?

the woman's right to culture under art 27 was breached, while one member also found a breach of the equality provision, art 26. See Lovelace $v$ Canada Comm No 24/1977: Canada 30/07/81, UN Doc CCPR/C/13/D/24/1977. M Nowak, UN Covenant on Civil and Political Rights: CCPR Commentary (Engel 1993) 469.

${ }_{99}$ See also UN Human Rights Committee (HRC), CCPR General Comment No 18: Nondiscrimination (10 November 1989) available at <http://www.refworld.org/docid/453883fa8. html> para 5 .

100 See generally the list of questions and issues raised with States after the submission of reports and before the consultative dialogue meetings: <http://tbinternet.ohchr.org/_layouts/ treatybodyexternal/TBSearch.aspx?Lang=en\&TreatyID=3\&DocTypeID=1>8

101 CEDAW Gen Rec 21 paras 41-49. CEDAW Gen Rec 29 paras 54, 55.

102 Detailed consideration of CEDAW's interactions with States including Australia, Canada, India, Nepal, Pakistan, Zimbabwe, Norway, The Netherlands, UK, France and Finland can be found in individual chapters in A Hellum and HS Aasen (eds), Women's Human Rights: CEDAW in International, Regional and National Law (Cambridge University Press 2015). 
Can they be guardians of their children? A good example of the concerns can be found in the list of questions to the report of Mongolia in 2015:

It is reported by alternative sources that, under the family law, divorce is not available to women who are pregnant or have a child under 1 year of age and that the law authorizes judges to impose a three-month reconciliation period before granting a divorce. In the report, the State party indicates that households headed by women account for 76.2 per cent of all households headed by single persons (p. 4). Please provide information on the measures taken to amend the discriminatory provisions and eliminate reconciliation periods and restrictions for women seeking a divorce. Please also provide information on the measures taken by the State party to protect single women heads of households and deserted wives with children, especially in situations in which those women are still officially married. ${ }^{103}$

Anti-discrimination principles have not only influenced the acceptance of new structures as constituting family, but also the content of the norms operating within those structures. For example, in ES and SC v Tanzania, two widows challenged customary laws that denied them the right to inherit from their husbands' estates. The CEDAW Committee found for the authors. In so doing, it invoked its General Recommendation 28 on State obligations and called on the State to change its laws, to train judges in human rights, to engage local leaders on removing discriminatory laws and to educate women about their rights. Significantly, the Committee found a violation of the little utilized Article 13 requiring the State to ensure that women enjoy economic opportunities including access to family benefits and financial services as well as allowing them to participate in cultural activities. ${ }^{104}$

The CEDAW Committee also sees culture and tradition as impediments to the enjoyment by women of their rights. In both General Recommendations and concluding observations, it calls on States Parties to abolish practices that it labels harmful. ${ }^{105}$ These include polygyny and bridewealth (called brideprice by the Committee). In General Recommendation 21 of 1994 it recommended that States discourage the practices. ${ }^{106}$ In its dialogue with States parties including Uganda, it linked the practice of bridewealth to violence against women, an assertion rejected by the Supreme Court of Uganda. ${ }^{107}$ By the time of its adoption of General Recommendation 29 in 2013, the CEDAW Committee had noted: 'This (bride gifts) practice should

$103 \mathrm{CEDAW} / \mathrm{C} / \mathrm{MNG} / \mathrm{Q} / 8-9$ : List of issues and questions in relation to the combined eighth and ninth periodic reports of Mongolia, para 21.

104 E.S. and S.C v Tanzania, CEDAW/C/60/D/48/2013, 13 April 2015, paras 7(2), 7(6), 7(8), 9. See also CEDAW, General Recommendation 34 on Rural Women para 55.

105 CEDAW Gen Rec 27, paras 8, 16; Gen Rec 29, para 2; Gen Rec 33, paras 8, 25; Gen Rec 34, para 8.

${ }_{106}$ Gen Rec 21, paras 14 and 16. The Committee reiterates this in Gen Rec 29, para 21.

107 CEDAW, Concluding Observations, Uganda, CEDAW/C/UGA/CO/7 para 20. Mifumi (U) and Anor. v Attorney-General and Another [2015] UGSC 13 at <http://www.ulii.org/node/25384>. 
not be in any way required in order for a marriage to be valid, and such agreements should not be recognized by the State party as enforceable.' 108

While a law or practice which gives men a right that is denied women does, on the face of it, constitute discrimination, denying polygyny in the terms it did in 1994 leaves those women in de facto polygynous units sorely exposed. ${ }^{109}$ The Committee appears to recognize this in General Recommendation 27 on older women in 2010 where it reiterates its opposition to the practice but goes on to recommend that in the event of the death of a polygynous husband, his property should be shared equally between his surviving wives and children; recognition perhaps, of social reality. ${ }^{110}$ While reiterating the position it took in 1994, General Recommendation 29 of 2013 acknowledges the persistence of the practice, and thus states: 'Accordingly, with regard to women in existing polygamous marriages, States parties should take the necessary measures to ensure the protection of the economic rights of women.' 111 In its most recent General Recommendation 34 on Rural Women, released to coincide with International Women's Day, 2016, the Committee noted: 'Rural women are also disproportionately affected by polygamy, which severely undermines equality in marriage and family relations.' Returning to the language of General Recommendation 21, it calls for States Parties to 'discourage and prohibit the practice of polygamous marriage'. 112

Even if a family relationship exists, its nature and quality are relevant to the degree of protection required. This is illustrated in Stewart v Canada where the HR Committee refused to rule that the deportation of a Scottish man who had been convicted of a crime constituted arbitrary and unlawful breach of his family life in breach of Articles 17 and 23 of the ICCPR. ${ }^{113} \mathrm{He}$ had said that he should be in close proximity to young twins by his ex-wife and his sick mother and disabled brother with whom he lived, but the Committee found that 'the nature and quality of his family relationships could be adequately maintained through correspondence, telephone calls and visits to Canada, which he would be at liberty to make pursuant to Canadian immigration laws'.114

108 Gen Rec 29, para 33. CEDAW appears to echo the Supplementary Convention on the Abolition of Slavery, the Slave Trade, and Institutions and Practices Similar to Slavery, 1956, Economic and Social Council resolution 608 (XXI) of 30 April 1956, art 1(c)(ii).

109 See C Nyamu-Musembi, 'Pulling Apart? Treatment of Pluralism in the CEDAW and the Maputo Protocol' in A Hellum and H Aasen, Women's Human Rights: CEDAW in International, Regional and National Law (Cambridge University Press 2013) 183-213.

${ }_{110}$ Gen Rec 27, para 53; see also para 28.

111 Gen Rec 29, para 28; see also para 21. The African Protocol on Women's Rights also appears to take a pragmatic position noting its preference for monogamous marriage, but going on to insist that women's rights in the family 'including in polygamous marital relationships are promoted and protected'. Protocol to the African Charter on Human and Peoples' Rights on the Rights of Women, OAU/AHG/Res. 240, art 6(c). 112 CEDAW Gen Rec 34, paras 32, 34

113 Comm No 538/1993: Canada. 16/12/96.CCPR/C/58/D/538/1993. 114 ibid para 9(4). 
While marriage would normally be a way of constituting a family, early marriage violates norms of the UNCRC, CEDAW, and the ICESCR. ${ }^{115}$ In its concluding observations to the second report of Yemen in 2011, the CESCR noted its deep concern:

...that the amendment to the Personal Status Act No. 20 of 1992 by Law No. 24 of 1999 , legalizing marriage for girls under 15 years of age with the consent of their guardians, remains in force and that in October 2010 the Parliamentary Sharia Committee prevented the entry into force of an amending act aimed at establishing a minimum age of marriage. The Committee is also concerned about the growing number of victims of child marriages (art 10). ${ }^{116}$

In General Recommendation 21 in 1994 the CEDAW Committee regarded 18 as earliest age that marriage should be permitted. It also enjoined States to ensure that the same age pertains to both sexes. Citing the World Health Organisation, the CEDAW Committee noted that early marriage is detrimental to the health of the girl child and impacts negatively on her ability to get an education which it turn impacts her 'economic autonomy.' 117 It further noted the negative impact on families and communities. ${ }^{118}$ It was clear that children do not choose to marry early and thus enjoined States Parties ensure that betrothal of girls in marriage is not permitted and also that marriage ages are equalized between men and women. The CEDAW Committee saw registration as providing protection for children and protecting against bigamy, early and forced marriage and polygny. ${ }^{119}$ All this is reiterated in CEDAW's joint comment with the UNCRC of 2014 and again in its General Recommendation 34 of 2016.120

The strongly normative approach of the CEDAW Committee is illustrated in its comments on de facto unions. It does not simply regard these as capable of constituting families, and giving rise to 'family life', but States should ensure equality within them. General Recommendation 21 noted:

Moreover, generally a de facto union is not given legal protection at all. Women living in such relationships should have their equality of status with men both in family life and in the sharing of income and assets protected by law. Such women

115 UN Committee on Economic, Social and Cultural Rights (CESCR), General Comment No. 14: The Right to the Highest Attainable Standard of Health (Art. 12 of the Covenant) (11 August 2000) E/C.12/2000/4, available at $<\mathrm{http}: / /$ www.refworld.org/docid/4538838d0.html $>$ para 22 . The African human rights system sets 18 as the minimum age for marriage. See ACRWC, art 21(2) and African Women's Protocol, art 6(b).

116 Concluding observations of the Committee on Economic, Social and Cultural Rights: Yemen (22 June 2011) E/C 12/YEM/CO/2, available at: <http://www.refworld.org/docid/52d673874.html> para $19 . \quad 117$ CEDAW Gen Rec 21, para $36 . \quad 118$ ibid para 37.

119 CEDAW Gen Rec 21, para 39.

120 Joint General Recommendation 31 of the Committee on the Elimination of Discrimination against Women/General Comment 18 of the Committee on the Rights of the Child on Harmful Practices. CEDAW/C/GC/31/CRC/C/ GC/18 (14 November 2014); CEDAW Gen Rec 34, paras 32,34 . 
should share equal rights and responsibilities with men for the care and raising of dependent children or family members. ${ }^{121}$

CEDAW's General Recommendation 29 of 2013 enjoins States to recognize the contribution made by women to family life and highlights the disadvantages faced by those in cohabiting and other relationships that do not receive legal sanction. ${ }^{122}$ Although expressing a preference for registration of customary marriages, it adds:

However, many States parties lack either a legal requirement of marriage registration or implementation of existing registration requirements, and in such instances individuals should not be penalized for failure to register, including where lack of education and infrastructure makes registration difficult.

Here the CEDAW Committee can be seen to be more pragmatic than the African Protocol on Women's Rights, which in Article 6(d) calls on registration of marriage as a prerequisite for validity. If rigorously enforced, many women could be left without protection in the event of repudiation or death without the existence of a valid will. The challenge posed is that, often, women are not consulted about the form that their particular unions should take. In its General Recommendation 33 on Access to Justice of 2015, the Committee appears to realize that it may not be enough to simply call for women's choices to be respected. Instead it enjoins the State to ensure that State courts should review any decisions made with respect to marital consequences. ${ }^{123}$

The CEDAW Committee recognizes that all family forms appear to throw up economic challenges for women. It is for this reason that it notes that where prenuptial contracts are entered into in anticipation of marriage, attention should be paid to mitigate any inequality of bargaining power in order to ensure that the agreement reached is fair. ${ }^{124}$ The CEDAW Committee identifies the growth of female-headed households which it says are disproportionately poorer. ${ }^{125}$ It focuses on the many ways in which women are denied an equal share of property on death and divorce. It calls on States to recognize the non-monetary contributions made by women to the family. ${ }^{126}$ These analyses are confirmed by the Committee in its 2016 General Recommendation 34 on Rural Women, in which it highlights the disproportionate impact of economic poverty on rural women especially female-headed households. ${ }^{127}$ They are burdened by practices such as 'the inheritance of ancestral debt'. Furthermore their work is both unrecognized and unremunerated. The Committee notes that rural women suffer discrimination in the allocation of land and also due to unfair inheritance

121 CEDAW Gen Rec 21, para 18.

123 CEDAW Gen Rec 33, para 46(c).

125 Gen Rec 29, para 4. See also Gen Rec 21, para 24.

122 Gen Rec 29, para 30.

126 Gen Rec 29, paras 39-53. See also the Dissenting Opinion in the inadmissible case-B. J. v Germany, UN Doc CEDAW/C/36/D/1/2003 (14 July 2004). See also Gen Rec 21, paras 11, 12, 26, $30-35$.

127 Gen Rec 34, para 14 . 
allocations which privilege males. ${ }^{128}$ Widows and older women are identified as suffering stigmatization and isolation which exposes them to greater risks of illtreatment. It pushes some to migrate and leaves others open to trafficking and exploitation. ${ }^{129}$ In its General Recommendation 33 on Access to Justice the CEDAW Committee enjoins States to consider setting up gender sensitive judicial frameworks which will ensure women fairness in the making of decisions on custody, divorce and distribution of property. ${ }^{130}$

Similarly, with regard to the ICESCR, the CESCR (Committee on Economic, Social and Cultural Rights) concerns itself with the material circumstances in which people live, and with this in mind, focuses its attention on requiring States to facilitate citizens to provide an adequate livelihood for themselves and their families. The CESCR reiterated its view that the family is frequently the site of discrimination. ${ }^{131}$ The CESCR is opposed to status discrimination focusing, in its General Comment 20, on birth:

Distinctions must therefore not be made against those who are born out of wedlock, born of stateless parents or are adopted or constitute the families of such persons. The prohibited ground of birth also includes descent, especially on the basis of caste and analogous systems of inherited status. ${ }^{132}$

From the categories of persons that the CESCR seeks to protect from discrimination, one can infer a wide construction of family similar to that used by the Committee on the Rights of the Child. ${ }^{133}$

128 Gen Rec 34, para 78. See also R Chandran, 'Forced by Tradition to Give up Inheritance, Indian Women Embrace Property Ownership' Thomas Reuter Foundation (2 November 2016) at $<$ http://www.reuters.com/article/us-india-landrights-women-idUSKBN12X1OZ $>$. See generally Land and Gender section on Landportal at $<$ https://landportal.info/book/thematic/land-andgender $>$.

${ }^{129}$ See also CEDAW Gen Rec 26 on Women Migrant Workers, CEDAW/C/2009/WP.1/R (5 December 2008).

${ }^{130}$ CEDAW General Recommendation 33 on access to justice, CEDAW/C/G/33 (3 August 2015) para 46(b).

131 CESCR General Comment 16, General Comment 20, para 11. See also UN Committee on Economic, Social and Cultural Rights (CESCR), General Comment 21, Right of everyone to take part in cultural life (art. 15, para 1a of the Covenant on Economic, Social and Cultural Rights) (21 December 2009) E/C.12/GC/21, available at <http://www.refworld.org/docid/4ed35bae2.html > paras 21-23, 25, 26-44.

132 CESCR General Comment 20, para 26. See also Comm No Com/002 Institute for Human Rights and Development in Africa and Open Society Justice Initiative on behalf of children of Nubian Descent and African Committee of Experts on the Rights and Welfare of the Child, General Comment No 2 on Birth, Registration, Name and Nationality, at $<$ http://www.acerwc. org/download/general_comment_article_6_name_and_nationality $/$ ?wpdmdl=8606 $>$.

133 CESCR General Comment 14 on the Highest attainable standard of health, E/C.12/2000/4 (11 August 2000) para 18; CESCR General Comment 15 on the Right to Water, E/C.12/2002/11 (20 January 2003) paras 13 and 16; CESCR General Comment 19 on Article 9, The Right to Social security E/C.12/GC/19 (4 February 2008) paras 28 and 29. 


\section{B. Violence}

In its General Comment 16 on equality between men and women, in 2005 the CESCR interpreted Article 10(3) of the ICESCR as requiring States parties:

... to provide victims of domestic violence, who are primarily female, with access to safe housing, remedies and redress for physical, mental and emotional damage; to ensure that men and women have an equal right to choose if, whom and when to marry - in particular, the legal age of marriage for men and women should be the same, and boys and girls should be protected equally from practices that promote child marriage, marriage by proxy, or coercion; and to ensure that women have equal rights to marital property and inheritance upon their husband's death. Gender-based violence is a form of discrimination that inhibits the ability to enjoy rights and freedoms, including economic, social and cultural rights, on a basis of equality. ${ }^{134}$

This linkage by the CESCR of domestic violence with discrimination is a theme that runs through the comments and jurisprudence on CEDAW, which, as seen above, includes a strong normative component in its perception of the family. The adoption in 1999 of the Optional Protocol to CEDAW has opened a new vista on CEDAW's work on the family. ${ }^{135}$ Many of its cases have related to violence against women in the family. The CEDAW Committee has drawn on its General Recommendation 19 on Violence against Women of 1992 in which it identified the family as the site of many violations of women's rights. ${ }^{136}$ This is an area where States are under a clear obligation to intervene in family life. This was seen in AT v Hungary in $2005^{137}$ where a violent man was not evicted from the family home because the couple were not married. The authorities had failed to deal with the physical, psychological as well as the economic violence caused by his failure to pay maintenance for over three years. CEDAW criticized the legal deference to men's property rights over those of the right to protection of women and children, as well as the State's failure to provide refuges that could accommodate the woman and her children, one of whom had a disability. The CEDAW Committee found violations of Articles 2(a), (b) and (e) (on State obligations) and Article 5(a) (on stereotyping) in conjunction with Article 16 (on marriage and family). In 2011, in Jallow v Bulgaria, ${ }^{138}$ the

134 GC 16 para 27.

135 Optional Protocol to the Convention on the Elimination of all Forms of Discrimination against Women, 1999, UNGA Res 54/4 (6 October1999) UN Doc A/RES/54/4.

136 CEDAW General Recommendation 19 on Violence against Women, UN Doc HRI/GEN/1/ Rev.9 (Vol II) paras 11, 22. See generally, C Chinkin 'Violence against Women' in MA Freeman, C Chinkin and B Rudolf(eds), The UN Convention on the Elimination of All Forms of Discrimination Against Women: A Commentary (Oxford University Press 2013) 443-74.

137 Comm No 2/2003, Views adopted, 26 January 2005, para 9. See also the recommendations that follow. See also Kell v Canada Comm No 19/2008; Views adopted by the Committee at its fiftyfirst session, 13 February to 2 March 2012 on the failure to protect an indigenous woman in a cohabiting relationship.

138 Comm No 32/2011, UN Doc CEDAW/C/52/D/32/2011 (28 August 2012). 
CEDAW Committee focused on the State's failure to protect a migrant woman from violence at the hands of her husband, noting that she had been particularly discriminated against because she lacked the language skills to navigate the justice system. The woman's complaints about the violence were not taken seriously by the police. However, when the husband retaliated and asked for a protection order, he was granted one without evidence of his previous violence having been taken into account. Despite the woman's protestations, he was also given custody of their child. She eventually agreed to a divorce accepting a poor settlement because she wanted her daughter to come to live with her. The Committee found many violations, concluding that 'both the author and her daughter are victims of gender-based discrimination because the State party failed to protect the author's equal rights in marriage and as a parent and to regard her daughter's interests as paramount'. ${ }^{139}$

The idea of family life posing a direct threat to a woman's right to life was explored in the 2005 cases Sahide Goecke v Austria and Yildrim v Austria. ${ }^{140}$ In both cases, the women were killed by their husbands after campaigns of violence. The focus of the CEDAW Committee's comments is on the State's failure to meet it due diligence obligations. The recommendations point to the need for States to set up early warning systems, an issue which has been taken up in the Council of Europe Protocol on Violence. ${ }^{141}$ In Gonzalez $v$ Spain, ${ }^{142}$ in 2014, the CEDAW Committee took the State to task for having failed to take into account the father's violence towards the mother (including in front of the child) when awarding him visitation rights. The father eventually killed the child and himself. The Committee found that in relying on the stereotype of a father's right to have contact with his child, the State had failed to properly exercise its due diligence obligations and had also ignored the child's best interests.

In the CEDAW Inquiry into the denial of contraception to women in the Philippines, ${ }^{143}$ the Committee found that denying women the right to plan their families, reinforced and exacerbated inequalities between men and women in the family, denied women their ability to make their way in society and 'reinforced gender stereotypes prejudicial to women, given that they incorporated and conveyed stereotyped images of women's primary role as child bearers and child rearers, thereby perpetuating discriminatory stereotypes already prevalent in Filipino society'. ${ }^{144}$ Article 16 has also been successfully invoked in a case on forced sterilization of a Roma woman. ${ }^{145}$

\footnotetext{
139 ibid para 8.6.

140 Sahide Goecke v Austria Comm No 5/2005, UN Doc CEDAW/C/39/D/5/200; Yildrim v Austria Comm No 6/2005, UN Doc CEDAW/C/39/D/6/2005 (1 October 2007).

141 Council of Europe Convention on preventing and combating violence against women and domestic violence, CETS No. 210, 2011, arts 49-58.

${ }_{142}$ Comm No 47/20 12, UN Doc CEDAW/C/58/D/47/2012 (2014).

143 Philippines Inquiry under Article 8 of the Optional Protocol, CEDAW/C/P.8/PHL/I (22 April 2015). $\quad 144$ ibid para 43. ${ }^{145} A S$ v Hungary, Comm No 4/2004, CEDAW/C/36/D/4/2004.
} 
Issues of domestic violence have arisen in the context of the ECHR in connection with Article 8.2 of the ECHR which sets out the grounds upon which interference with the right to private and family life, home and correspondence can be justified. To these must be added the principle that any interference must be 'proportionate'. The ECtHR has confirmed, in Opuz $v$ Turkey, ${ }^{146}$ in 2009 , that States are under a positive duty to take appropriate and proportionate action to protect the right of all individuals to life (Article 2) and not to be subjected to torture or inhuman or degrading treatment or punishment (Article 3), and if the fulfilment of this duty involves interference with an individual's Article 8 rights, for example, by prosecuting or removing a violent husband from the home, then this interference will be justified. This conclusion effectively demonstrates that a family riven by violence does not constitute 'family life' in need of protection: rather, there are more important individual rights which require protection against what occurs in such a socalled 'family'.

Cases of domestic violence similar to that which occurred in Opuz v Turkey have also been dealt with by the Inter-American Commission on Human Rights. One of the most important was Fernandez v Brazil (Maria da Penha) where in 2000 it held Brazil to be in breach of the ACHR with respect to injuries inflicted as a result of domestic violence in 1983, nine years before the ACHR became binding on Brazil, by reason of the State's failure to take any appropriate action. ${ }^{147}$ The Commission made a number of recommendations which led to removal of inequalities in the marriage law (and thus a change in the nature of the marital family) and the Maria da Penha Law (1134/2006) specifically aimed at violence against women. ${ }^{148}$ Commenting on a Colombian case, the Commission stated in 2014 that: ${ }^{149}$

Violence against women shall be understood to include physical, sexual and psychological violence: (a) that occurs within the family or domestic unit or within any other interpersonal relationship, whether or not the perpetrator shares or has shared the same residence with the woman, including, among others, rape, battery and sexual abuse; (b) that occurs in the community and is perpetrated by any person, including, among others, rape, sexual abuse, torture, trafficking in persons, forced prostitution, kidnapping and sexual harassment in the workplace, as well as in educational institutions, health facilities or any other place.

146 Opuz v Turkey Appl No 33401/02, Judgment of 9 September 2009.

147 Case 12.051, IACHR Rep No 54/01, OEA/Serv. L/V/II.III, deoc 20, 1-2 (2000).

148 See P Spieler, 'The Maria da Penha Case and the Inter-American Commission on Human Rights: Contributions to the Debate on Domestic Violence against Women in Brazil' (2011) 18 Indiana Journal of Global Legal Studies 121.

149 Inter-American Commission on Human Rights, Legal Standards Related to Gender Equality and Women's Rights in the Inter-American System: Development and Application: Updates 20112014, para 83. 
The use of the expression 'domestic unit' in addition to 'family unit' in its understanding of violence against women recognizes that the characteristic of this form of violence against women lies not so much in the family relationship that may or may not exist between the perpetrator and the victim, but in the intimate nature of the setting.

\section{REFLECTIONS AND CONCLUSIONS}

This part concludes the article by trying to identify underlying drivers of change which could bring about a common understanding of family and how they address human rights violations within and support for families, but also considers international and domestic challenges to these developments.

Perhaps the most important drivers of change have been the antidiscriminatory norms either implicit or explicit within the conventions, and it is this element that links many of these developments together. As stated earlier, this has been said to be a major component of what is seen as an emerging 'European' family law, an early manifestation appearing in the seminal Marckx case. ${ }^{150}$ Although this was focused on the parent-child relationship, the court's observations embraced the discriminatory effects of distinguishing between a 'legitimate' and 'illegitimate' family, which clearly has implications also for the relationship between the adults. It stated:

The Court concurs entirely with the Commission's established case-law on a crucial point, namely that Article 8 makes no distinction between the 'legitimate' and the 'illegitimate' family. Such a distinction would not be consonant with the word 'everyone', and this is confirmed by Article 14 with its prohibition, in the enjoyment of the rights and freedoms enshrined in the Convention, of discrimination grounded on 'birth'. In addition, the Court notes that the Committee of Ministers of the Council of Europe regards the single woman and her child as one form of family no less than others (Resolution (70) 15 of 15 May 1970 on the social protection of unmarried mothers and their children, para I-10, para II-5, etc). ${ }^{151}$

We noticed how the same norms against discriminating against children of married and unmarried parents was found also in the African Charter of the Rights and Welfare of the Child 1990. The gradual inclusion of unmarried opposite-sex couples into the concept of the family, extending eventually to same-sex couples, not only under the ECHR, but also the IAHC and by CEDAW, was also driven by anti-discrimination principles. ${ }^{152}$ But other normative principles are emerging that have potential to become additional drivers in the newly emerging social constructions of the family. One is the principle of the 'best interests' of the child, especially in the context of parenthood following use of artificial reproductive technology and also the

150 Appl No 6833/74, Judgment of 13 June 1979. See Scherpe (n 89).

152 See Pt II. 
protection of the child and other parent from familial violence. Another potentially significant driver has appeared in the jurisprudence of the IACHR in the form of the concept of the 'life plan'. The idea that individuals are entitled to a 'decent' life, and as expressed in the judgment of Justice Marco Aurelio in the Federal Supreme Court of Brazil on 5 May 2011 referred to earlier ${ }^{153}$ reflects the role of 'dignity' in human rights discourse. ${ }^{154}$ Both 'best interests' and 'dignity' have great potential for redefining the structural elements that constitute the 'family' across the human rights institutions. The South African Constitutional Court recognized this when it decided that the absence in the 1996 draft Constitution of a reference to a right to marry or to family life did not invalidate the Constitution, since 'families are constituted, function and are dissolved in a variety of ways' 155 and 'families come in many shapes and sizes. The definition of the family also changes as social practices and traditions change.' 156 Yet it has still proved possible under the Constitution to protect the right to family living without the need to define 'family' through the right to respect for dignity, which, coupled with the right to equality, eventually went as far as to give same-sex couples the right to marry. ${ }^{157}$

The presence of normative drivers that relate to the protection of individuals (especially against discrimination and violence) and the enhancement of their well-being raise the difficult question whether the object of human rights law should be to protect families or to protect individuals within families. The intention to protect families is clearly stated in a number of provisions. ${ }^{158}$ Some of these can be read as intending to protect individual family members, such as the duty to ensure 'decent living for themselves and their families' in Article 7(ii) of the ICESCR. But in other cases it seems to be the 'unit' that is protected. However, the discussion in Part III shows that the human rights bodies have not permitted the protections given to the family in the relevant instruments to stand in the way of the duties they impose on States to protect individuals when this is necessary. Notably in Opuz v Turkey ${ }^{159}$ in 2009 the ECtHR brought together the responses of CEDAW, the IAHCR as well as its own precedents in spelling out, again, the duties of States to offer proper protection against violence. The protection that individuals are entitled to is

153 See Inter-American Commission on Human Rights, Legal Standards Related to Gender Equality and Women's Rights in the Inter-American Human Rights System: Development and Application, Updates 2011-2014.

${ }_{154}$ See C McCrudden, 'Human Dignity and Judicial Interpretation of Human Rights' (2008) 19 EJIL 655; T Khaitan, 'Dignity as an Expressive Norm: Neither Vacuous Nor a Panacea' (2012) 32 OJLS 1; S Fredman, 'Foreign Fads or Fashions: The Role of Comparativism in Human Rights Law (2015) 64 ICQL 631.

155 In re Certification of the Constitution of the Republic of South Africa 19961996 (4) SA 744 (CC) para 99.

156 Rahim Dawood \& ors v Minister of Home Affairs \& ors 2000 (3) SA 936, para 31.

157 Minister of Home Affairs v Fourie 2006 (1) SA 524 (CC).

158 See ACHR, art 17; ICCPR, art 23; ICESCR, art 10.

159 Appl No 33401/02, Judgment of 9 September 2009. 
from arbitrary interference in their enjoyment of family life. This includes their right to live together and not to be split up by immigration or nationality laws that deny family reunification or deportation without good cause.

Furthermore, the 'right to family life', which must be respected under Article 8 of the ECHR, is clearly an individual right. It has indeed often been seen as being included in the right to 'private' life (although the latter is wider). So whether or not the terms 'family' and 'family life' are sites of rights themselves, they are certainly proposed as conditions to which individuals have rights. Part II of this article shows how the protection of these individual rights has brought about modifications to the understanding of the structure of families at international level. 